\title{
Aleksandra Sznajdrowska-Pondel
}

(rev.) Tomasz J. Chmielewski and Edmund Mitrus (eds.), Pliszczyn, site no. 9. Eneolithic complex in the Lublin region (= Saved Archaeological Heritage 5). Pękowice - Wrocław 2015: Profil-Archeo Publishing House and Archaeological Studio, Archaeologia Silesiae Science Foundation, 248 pages, 71 figures, 34 tables and 21 plates in the text, published in Polish and English.

Pliszczyn, site 9 was published as the $5^{\text {th }}$ volume of Saved Archaeological Heritage series that presents results of rescue excavations. The book contains 13 chapters, most of which are written by Tomasz Jacek Chmielewski. Only the specialist analyses were written by experts in given fields. The publication ends with an extensive bibliography including both Polish and foreign literature. The authors decided to publish the book in two languages (Polish and English), which will definitely help to spread the results of the excavation.

The foreword by Chmielewski and Edmund Mitrus mentions the main objective of the work that is the presentation of the sources acquired during the rescue excavation on Pliszczyn 9 site connected with The Funnel Beaker Culture (FBC). In this part of the book the authors also thank all the people who contributed, both during the fieldwork and editing stages, to creating the publication.

Chmielewski presented all the basic site data in the first chapter, which covers the fieldwork stage. This chapter includes the history of the research as well as a detailed description of the research and documentation methodology used during the exploration.

The chapter presenting the environmental determinants of the location of the settlement, written by Renata Kołodyńska-Gawrysiak, is an important part of the publication. The author carried out a detailed analysis of the geological structure, the landforms, the soil cover and hydrologic regime of the site area. The analysis showed that the FBC people's decision to settle there was absolutely justified as the location offered all the necessary resources.

In the third chapter, Chmielewski presents the state of preservation of the site. The analysis includes both the natural (leaching and bioturbation) and anthropogenic (agro- 
technical activities) processes. Many monographs lack this kind of analysis or they include only rather superficial ones. The subject of site formation processes, however, has started to be thoroughly discussed recently (e.g. Rzepecki 2014; Kośko and Szmyt 2006). It offers the opportunity to understand the processes behind settlement formation as well as to accurately interpret some phenomena.

The next part of the work presents the spatial development of the FBC settlement in Pliszczyn and the form and size of the features found there. Using the measurement data, the shape and type of the fills, microstratigraphy and the analysis of the material found in the fills, the author determines the function of the features. He also attempts to reconstruct the process of fill creation in some of the pits with complicated stratigraphy (e.g. feature 10). On the other hand, the author does not take into consideration the weight or fragmentation of the material found in the pits while these parameters are essential for such analysis according to the methodology developed by Sławomir Kadrow (1991). There is also no data, even the most essential one, related to the amount of the material found in given features.

Moveable sources (ceramic materials) were discussed in the fifth chapter. To characterize the ceramic material, the author uses the classification system created by Witold Gumiński (1989). Spindle whorls classification is based on the typology used in the Gródek Nadbużny monography (Gumiński 1989) and on the typology created by the author and Leszek Gardyński (Chmielewski, Gardyński 2009). Describing the ceramic vessels, the author briefly characterizes the production technology and the forming, finishing and firing techniques. Gumiński's classification that is used by the author to identify the types of the vessels seems to be, however, somewhat problematic. The classification is different from the other typologies that are commonly used (e.g. Kośko 1981) in terms of the terminology as well as the number and type of vessels it characterises. Although according to the author, Gumiński's classification is the most suitable one when it comes to presenting the changing vessel forms in the South-Eastern group of the FBC, the classification itself was not, in fact, used in the publication. The conclusions drawn from the comparison of the vessel forms discovered in Pliszczyn with those found on other FBC archaeological sites are limited to the statement that the forms are representative of the South-Eastern group.

The next two chapters discuss flint finds and stone finds. The former are presented by Chmielewski and the latter are characterized by Chmielewski and Kołodyńska-Gawrysiak. In the sixth chapter, the author describes the raw material structure of the artefacts made with the use of flint working techniques and he also characterizes other categories of tool and non-tool forms. When it comes to the stone artefacts, a macroscopic analysis of the raw material was carried out as well. The following tools were identified in the assemblage: hammerstone-grinders, whetstone slabs and one example of a granite axe blade turned into a hammerstone grinder.

Both features and materials presented in the previous chapters were connected with the FBC settlement discovered in Pliszczyn. The settlement area also included a cemetery 
with two megalithic tombs where 10 burials were discovered. The burial area arrangement and the burial customs characteristics were comprehensively discussed in the eighth chapter. The detailed description of the tombs, burials and grave goods includes a vast number of pictures and a table with the key information concerning particular burials. The relation between the residential and economic area and the burial ground pointed by the author seems to be very interesting. They were separated by an empty strip of land with a single household pit and there was a deceased interred at its bottom.

The monograph is enriched with some specialist analyses. The archaeobotanic analysis was carried out by Agata Sady. The author of the archaeozoological analysis was Daniel Makowiecki. Moreover, in the eleventh chapter written by Wanda Kozak-Zychman and Anna Szarlip, there are interesting comments concerning the anthropological materials. The archeobotanic data from the grave no. 1 is especially interesting. Burnt pieces of oak wood and partially burnt fragments of birch bark indicate that there was an oaken structure padded with birch bark in the pit. Faunal material that belongs to a crayfish was another significant discovery on the archaeological site in Pliszczyn. The find is, at the moment, the oldest proof that the species was consumed in Polish territory. The comprehensive specialist analyses of floral, faunal and human remains are the sources of valuable comparative data for other FBC sites in Lublin region.

To specify the chronology of the settlement and funeral complex, radiocarbon analysis of human bones from burials no. 3 and 5 were carried out, and it is discussed in the twelfth chapter. The data obtained during the analysis indicates that the complex belongs to the classical phase of the South-Eastern FBC group. It also indicates that the northern tomb was the first to be built in the cemetery.

The work meets all the requirements for an investment research monograph. It is a valuable source of information in studies of the south-eastern FBC group both in local and more general contexts. The interdisciplinary research on the settlement and funeral complex in Pliszczyn will most probably become an important point of reference in future studies. The fact that there are no other settlements recognized on the site seems to be the key factor. It allowed the author to draw some accurate conclusions concerning organization of the space on the site and its clear sacrum-profanum division. The monograph is also an important contribution to the analysis of loess sites creation. What is more, the new radiocarbon dates presented in the work extend the rather modest amount of such data for FBC in Lublin region.

\section{References}

Chmielewski T. J. 2009. Po nitce do ktębka... O przędzalnictwie i tkactwie młodszej epoki kamienia $w$ Europie Środkowej. Warszawa: Semper.

Chmielewski T. J. and Gardyński L. 2009. Włókno - nić - wrzeciono. Z metodyki badań przęślików na przykładzie znalezisk ze stanowiska $1 \mathrm{C}$ w Gródku. In H. Taras and A. Zakościelna (eds.), 
Hereditas praeteriti: Addimenta archaeologica et historica dedicate Ioanni Gurba Octogesimo Anno Nascendi. Lublin: Wydawnictwo UMCS.

Gumiński W. 1989. Gródek Nadbużny. Osada kultury pucharów lejkowatych. Wrocław: Ossolineum.

Kadrow S. 1991. Iwanowice. Stanowisko Babia Góra 1. Rozwój przestrzenny osady z wczesnego okresu epoki brqzu. Kraków: Instytut Historii Kultury Materialnej PAN.

Kośko A. 1981. Udziat południowo-wschodnio-europejskich wzorców kulturowych $w$ rozwoju niżowych spoleczeństw kultury pucharów lejkowatych. Grupa mątewska (= Seria Archeologia 19). Poznań: Uniwersytet im. Adama Mickiewicza.

Kośko A. and Szmyt M. 2006. Opatowice-Wzgórze Prokopiaka 1. Poznań: Wydawnictwo Poznańskie. Rzepecki S. 2014. Wilkostowo 23/24. Neolityczny kompleks osadniczy 1 (= Spatium Archaeologicum 8). Łódź: Instytut Archeologii Uniwersytetu Łódzkiego, Fundacja Uniwersytetu Łódzkiego.

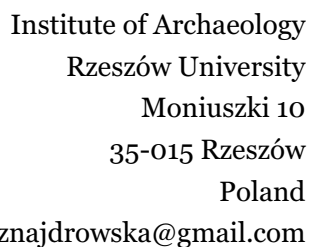

